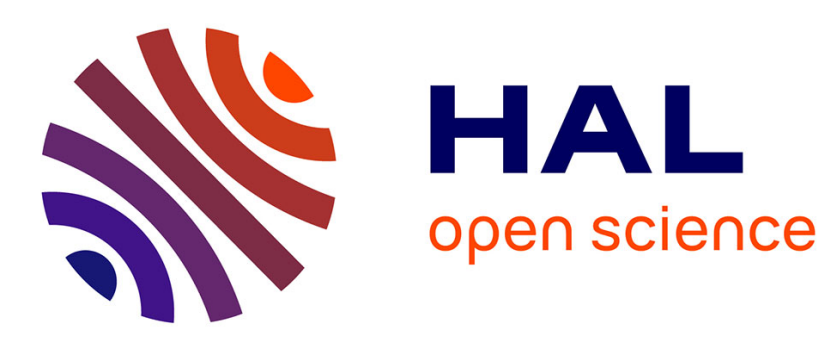

\title{
Zic Genes in Nematodes: A Role in Nervous System Development and Wnt Signaling
}

Guillaume Bordet, Vincent Bertrand

\section{To cite this version:}

Guillaume Bordet, Vincent Bertrand. Zic Genes in Nematodes: A Role in Nervous System Development and Wnt Signaling. Zic family / Evolution, Development and Disease, 1046, pp.59-68, 2018, 10.1007/978-981-10-7311-3_4. hal-02014093

\section{HAL Id: hal-02014093 \\ https://hal.science/hal-02014093}

Submitted on 11 Feb 2019

HAL is a multi-disciplinary open access archive for the deposit and dissemination of scientific research documents, whether they are published or not. The documents may come from teaching and research institutions in France or abroad, or from public or private research centers.
L'archive ouverte pluridisciplinaire $\mathbf{H A L}$, est destinée au dépôt et à la diffusion de documents scientifiques de niveau recherche, publiés ou non, émanant des établissements d'enseignement et de recherche français ou étrangers, des laboratoires publics ou privés. 


\title{
Zic genes in nematodes : a role in nervous system development and Wnt signaling
}

Guillaume Bordet and Vincent Bertrand*

Aix-Marseille Université, CNRS, Institut de Biologie du Développement de Marseille, 13288 Marseille cedex 9, France

* corresponding author: Vincent Bertrand, vincent.bertrand@univ-amu.fr

\begin{abstract}
Transcription factors of the Zic family play important roles during animal development and their misregulation has been implicated in several human diseases. Zic proteins are present in nematodes and their function has been mostly studied in the model organism C. elegans. C. elegans possesses only one Zic family member, REF-2. Functional studies have shown that this factor plays a key role during the development of the nervous system, epidermis and excretory system. In addition, they have revealed that the $C$. elegans Zic protein acts as an atypical mediator of the Wnt/ $\beta$-catenin pathway. In other animals including vertebrates, Zic factors are also regulators of nervous system development and modulators of Wnt signaling, suggesting that these are evolutionary ancient functions of Zic proteins.
\end{abstract}

\section{Keywords}

Zic, nematodes, C. elegans, transcription, development, nervous system, Wnt signaling 


\section{Introduction}

The phylum Nematoda is a very large and diverse group of animals that belongs to the clade Ecdysozoa. It contains both free-living and parasitic animals including human pathogens. The most studied nematode is Caenorhabditis elegans. Since the late $70 \mathrm{~s}$ it has become a major model organism for research in various fields including genetics, molecular biology, development and neurobiology. Because of its short life cycle, it is a powerful model to conduct genetic screens (Brenner 1974). In addition, with its transparency, small number of somatic cells (959 in the adult hermaphrodite) and fixed lineage, it is an excellent system to study development in vivo at single cell resolution (Sulston and Horvitz 1977; Sulston et al. 1983).

The sequencing of the $C$. elegans and human genomes has revealed that 60 to $80 \%$ of human genes have a homolog in C. elegans, and C. elegans has been extensively used to characterize the function of many of these conserved gene families (Kaletta and Hengartner 2006). A single member of the Zic transcription factor family is present in C. elegans, making it easy to study. This family plays key roles during the development of various animals including vertebrates. In addition, misregulation of Zic factors is involved in several human diseases. Here, we will review the studies that have been conducted on the C. elegans Zic factor. We will first present its structure, then describe its function during development of the nervous system, the epidermis and the excretory system. Finally, we will present its role as mediator of Wnt signaling.

\section{Structure of the Zic gene of C. elegans, ref-2}

C. elegans has only one Zic family gene, ref-2 (Alper and Kenyon 2002; Aruga et al. 2006). The name ref-2 (regulator of fusion-2) corresponds to the phenotype of the first mutant identified for this gene, which presents a defect in the fusion pattern of ventral epidermal cells (Alper and Kenyon 2002). An analysis of several other nematode species for which the genome is available (Brugia malayi, Onchocerca volvulus, Pristionchus pacificus, Panagrellus redivivus, Strongyloides ratti) suggests that they also possess only one Zic family gene. In C. elegans, the Zic protein REF-2 
presents two isoforms: a short isoform REF-2a (303 amino acids) and a long isoform REF-2b (315 amino acids) (Fig. 1A). They result from the use of alternative transcription start sites, REF-2b having 12 additional amino acids at the N-terminal end. The most abundant isoform is REF-2a. The C. elegans REF-2 proteins possess the five $\mathrm{C} 2 \mathrm{H} 2$ type zinc fingers characteristic of the Zic protein family (Fig. 1B). The degree of conservation of the zinc fingers 2 to 5 is very high while zinc finger 1 is less conserved. Some Zic family proteins in various animal species also contain two additional conserved domains: ZOC (Zic/Odd-paired conserved) and ZF-NC (zinc finger N-terminal flanking conserved). The ZOC domain is only present in the long isoform of the C. elegans protein (REF2-b), while the ZF-NC domain is absent in both isoforms (Aruga et al. 2006; Layden et al. 2010).

Several mutations in the ref-2 gene have been isolated. The first mutation isolated, mu218, is a gain of function mutation in a cis-regulatory element located just 3 ' to the coding region (Fig. 1A) (Alper and Kenyon 2002). This mutation leads to an ectopic expression of ref-2 in some ventral epidermal cells. Two loss of function mutations have subsequently been identified: ot327 is a point mutation in zinc finger 4 that converts a key cysteine into a tyrosine and is predicted to result in a loss of DNA binding activity for zinc finger 4 (Fig. 1A,B), gk178 is a deletion resulting in a frame shift that removes the five zinc fingers and is likely a null allele (Fig. $1 \mathrm{~A}$ ) (Bertrand and Hobert 2009). Both loss of function alleles give identical phenotypes (Bertrand and Hobert 2009).

\section{Role of REF-2/Zic during C. elegans development}

\section{1 nervous system development}

Functional studies have demonstrated that the C. elegans Zic gene ref-2 plays an important role during the development of the nervous system. In C. elegans, the nervous system is composed of 302 neurons in the hermaphrodite (Hobert 2016). Most of them are generated during embryogenesis by a series of invariant asymmetric divisions (Sulston et al. 1983). In the embryo, REF-2 is expressed in many (but not all) neuronal precursors before their terminal divisions (Bertrand and Hobert 2009). The REF-2 protein subsequently disappears from most neuronal 
lineages and its expression is restricted to only a few postmitotic neurons at larval and adult stages.

In ref-2 loss of function mutants the global organization of the nervous system is normal. While many neuronal subtypes are correctly specified, the generation of a few subtypes is defective (Bertrand and Hobert 2009). For example there is a defect in the specification of the interneurons AIY and AVK. The mode of action of REF-2 has been best characterized in the case of the AIY cholinergic interneuron (Fig.2) (Bertrand and Hobert 2009; Bertrand et al. 2011; Murgan et al. 2015). The identity of the AIY neuron is specified by two terminal selector transcription factors of the homeodomain family: TTX-3 (a LHX2/9 ortholog) and CEH-10 (a CHX10 ortholog) (Hobert et al. 1997; Altun-Gultekin et al. 2001; Wenick and Hobert 2004). TTX-3 and $\mathrm{CEH}-10$ are expressed in the postmitotic AIY neuron throughout the life of the animal, where they directly activate and maintain the expression of a large battery of AIY-subtype-specific terminal differentiation genes such as specific neurotransmitter receptors or ion channels (Wenick and Hobert 2004). In ref-2 mutants, the AIY neuron still expresses pan-neuronal markers but looses its specific subtype identity (Bertrand and Hobert 2009). The expression of TTX-3, CEH-10 and the battery of AIY-specific terminal differentiation genes is lost. During embryonic development REF-2 is transiently expressed in the mother cell of the AIY neuron before its terminal division but then disappears from the AIY lineage after the terminal division. REF-2 directly activates the expression of $t t x-3$ in the mother cell of AIY by binding to a Zic site present in the $t t x-3$ cis-regulatory region. To activate $t t x-3$ expression, REF2 cooperates with several proneural bHLH transcription factors $(\mathrm{HLH}-2, \mathrm{HLH}-3$ and $\mathrm{HLH}-16)$ that bind bHLH sites close to the Zic site in the ttx-3 cis-regulatory region (Bertrand and Hobert 2009; Bertrand et al. 2011; Murgan et al. 2015). ttx-3 then activates ceh-10 expression in the postmitotic AIY neuron, and ttx-3 and ceh-10 subsequently automaintain their expression throughout the life of the neuron. Therefore, the Zic factor REF-2 acts transiently in a neuronal precursor to initiate a neuronal subtype-specific differentiation program.

Interestingly, Zic factors also play a role in the development of the nervous system in many animal species. Zic genes are expressed in the developing nervous system in deuterostomes (vertebrates, amphioxus, ascidians) (Aruga 2004), protostomes (Drosophila, annelids) (Cimbora and Sakonju 1995; Takahashi et al. 2008; Layden et al. 2010) and cnidarians (Lindgens et al. 2004; Layden et al. 2010). 
Thus, the role of Zic factors in neuronal specification observed in nematodes may reflect an ancient metazoan feature.

\section{2 epidermis development}

The Zic gene ref-2 was initially isolated in a genetic screen for mutants affecting the fusion of the Pn.p ventral epidermal cells (Alper and Kenyon 2002). In the $C$. elegans larva, some of the ventral epidermal cells fuse with a large epidermal syncytium (hyp7) while some others don't fuse. REF-2 is expressed in the ventral epidermal cells and its expression last longer in cells that do not fuse. When ref-2 function is reduced using RNA interference all ventral epidermal cells fuse. Conversely, an overexpression of REF-2 using a ubiquitous driver or a gain-offunction mutation in the ref-2 cis-regulatory regions (mu218) prevents ventral epidermal cells from fusing. Therefore, the REF-2 protein keeps ventral epidermal cells from fusing. A stronger reduction of ref-2 function using higher concentrations of double stranded RNA leads to defects in the generation of the ventral epidermal cells. The ref-2 gene genetically interacts with two Hox genes, lin-39 and mab-5, to modulate ventral epidermal cell fusion (Alper and Kenyon 2002). However, the detailed molecular mechanism through which the REF-2 protein regulates cell fusion remains to be determined.

\section{3 excretory system development}

The C. elegans Zic factor REF-2 also plays a role during the development of the excretory system (Bertrand and Hobert 2009). The excretory system of $C$. elegans is composed of three cell types: the excretory cell, the duct cell and the pore cell (Sundaram and Buechner 2016). This system ensures the osmotic balance as well as the elimination of waste from the body. The excretory cell collects fluids that are then sent outside by the duct cell and the pore cell. During development three different cells successively fulfill the function of pore cell (G1, G2 and then its daughter G2p). REF-2 is expressed during development in G1 and in the $\mathrm{G} 2$ lineage (Bertrand and Hobert 2009). In addition, ref-2 loss of function mutants die at early larval stages with a phenotype characteristic of defects in the function of the excretory system (the pseudocoelome fills with fluid) (Bertrand and Hobert 2009; 
Nelson and Riddle 1984). Two gland cells, the excretory gland cells, are associated with the excretory system (Sundaram and Buechner 2016). These cells are not required for the viability of the animal and their function remains obscure. REF-2 is expressed in the excretory gland cells and is needed for the expression of the excretory gland marker lim-6 (Bertrand and Hobert 2009). Therefore, REF-2 seems required for the correct development and function of the excretory system but the detailed molecular mechanism awaits further characterization.

\section{Role of REF-2/Zic in Wnt signaling}

The Wnt/ $\beta$-catenin signaling pathway plays key roles during animal development (MacDonald et al. 2009; Clevers and Nusse 2012). This pathway is present in all animals from sponges to human. When this pathway is active, the transcriptional coactivator $\beta$-catenin is stabilized and interacts with a transcription factor of the T-cell factor (TCF) family. This $\beta$-catenin:TCF complex activates the transcription of "classic" target genes of the pathway via TCF binding sites present in their cisregulatory regions (Fig. 3). When the pathway is inactive, $\beta$-catenin is degraded and TCF represses the expression of the "classic" target genes. While most direct target genes follow this "classic" type of regulation, a few other direct target genes have been observed to follow an "opposite" type of regulation. These "opposite" target genes are repressed by the $\beta$-catenin:TCF complex and activated by TCF in the absence of $\beta$-catenin (Fig. 3) (Hoverter and Waterman 2008; Cadigan 2012; Murgan and Bertrand 2015). Interestingly, it has been recently observed in C. elegans that REF-2 is involved in this atypical regulation by TCF during the asymmetric divisions of neuronal precursors in the embryo (Murgan et al. 2015).

In the $C$. elegans embryo several asymmetric divisions oriented along the antero-posterior axis are regulated by a variant of the $\mathrm{Wnt} / \beta$-catenin cascade named the Wnt/ $\beta$-catenin asymmetry pathway (Kaletta et al. 1997; Lin et al. 1998; Mizumoto and Sawa 2007; Phillips and Kimble 2009; Sawa and Korswagen 2013; Bertrand 2016). This pathway regulates transcription via the formation of a complex between a TCF transcription factor named POP-1 and a $\beta$-catenin named SYS-1. Following asymmetric division, this pathway is active in the posterior daughter cell but not in the 
anterior daughter cell. The expression of the $t t x-3$ transcription factor gene is activated in the AIY mother cell (anterior daughter cell), where the Wnt/ $\beta$-catenin pathway is inactive, but not in the posterior daughter cell, where the pathway is active. This "opposite" regulation by the $\mathrm{Wnt} / \beta$-catenin pathway of the $t t x-3$ target gene is mediated by REF-2 (Fig. 3) (Murgan et al. 2015). In the anterior daughter cell, the TCF protein forms a complex with the REF-2 protein and this TCF:REF-2 complex activates $t t x-3$ expression via a Zic binding site present in its cis-regulatory regions. In the posterior daughter cell, $\beta$-catenin binding to TCF blocks the activation by the TCF:REF-2 complex. This is an atypical mode of action for a TCF transcription factor and whether other "opposite" target genes are regulated in a similar manner remains to be determined.

Interestingly, Zic factors have been shown to interact with the Wnt/ $\beta$-catenin pathway in other organisms as well. In vertebrates, Zic proteins bind TCF proteins (Zic2 binds TCF4, and Zic3 binds TCF1 and TCF3) (Pourebrahim et al. 2011; Fujimi et al. 2012). In addition, Zic factors block the expression of classic target genes of the Wnt/ $\beta$-catenin pathway in mammalian cell cultures and in Xenopus embryos (Pourebrahim et al. 2011; Fujimi et al. 2012). The mechanism of repression has been characterized for Zic2 (Pourebrahim et al. 2011). Zic2 binds the TCF-4: $\beta$-catenin complex at the level of cis-regulatory elements containing TCF sites, and this Zic2 binding blocks the ability of the TCF-4: $\beta$-catenin complex to activate transcription. Although this mechanism occurs on TCF sites, it is reminiscent of the situation observed in $C$. elegans on Zic sites: in both cases the Zic:TCF: $\beta$-catenin association is unable to activate transcription. Interestingly, it has been recently observed that in ascidian also a Zic protein physically interacts with a TCF factor (Oda-lshii et al. 2016). This suggests that modulating the response to the $\mathrm{Wnt} / \beta$-catenin pathway via a direct interaction with TCF is a general function of Zic factors in animals.

\section{Conclusion}

For many years $C$. elegans has been used as a model organism to characterize the function of several conserved gene families (Kaletta and Hengartner 2006). C. elegans has one Zic family member and so far only few functional studies 
have been conducted to determine its role during development. However, these studies have revealed several interesting properties that seem to be shared with other animals. The $C$. elegans Zic factor plays an important role during nervous system development, a property conserved in many animals from cnidarians to vertebrates, suggesting that it represents an ancient function of Zic factors. In $C$. elegans, Zic is not required for the generation of neurons in general, but it plays a role in the specification of some neuronal subtypes. Its mode of action has been characterized in one specific cholinergic lineage where it acts transiently in the neuronal precursor to initiate the terminal differentiation program. It will be interesting to determine whether Zic acts at a similar step in the specification cascade of the other neuronal subtypes that it regulates.

C. elegans studies have also revealed that Zic directly interacts with TCF and plays a role in the transcriptional regulation by $\mathrm{Wnt} / \beta$-catenin signaling. Zic factors bind TCF and modulate the activity of the Wnt/ $\beta$-catenin pathway in other animals as well, pointing towards an ancestral property of Zic proteins. In C. elegans, Zic interacts with TCF to regulate the expression of "opposite" target genes of the Wnt pathway. This atypical mode of action for TCF has so far only been observed for one target gene. It will be important to determine whether a similar mechanism regulates the expression of other "opposite" target genes in C. elegans and if this mode of action is conserved in other animals.

\section{Acknowledgments}

We thank Harold Cremer, Antoine Barrière and Sabrina Murgan for comments on the manuscript. Work in the V.B. lab is funded by an ATIP/Avenir startup grant from CNRS/INSERM, grants from the Fédération pour la Recherche sur le Cerveau and from the Agence Nationale de la Recherche (ANR-14-CE11-0001 and ANR-11LABX-0054).

\section{Figure legends}

Figure 1 Structure of the C. elegans Zic gene ref-2.

A) Organization of the ref-2 locus. B) Alignment of the zinc finger region of the REF-2 protein with the corresponding region of the five human Zic proteins. 
Figure 2 Role of the C. elegans Zic protein REF-2 in the initiation of the terminal differentiation program of the AIY cholinergic interneuron.

In the AIY mother cell, REF-2 cooperates with proneural bHLH factors (HLH-2, HLH3 and $\mathrm{HLH}-16)$ to initiate the expression of the terminal transcription factor TTX-3. After terminal division, TTX-3 activates the expression of the terminal transcription factor $\mathrm{CEH}-10$ in the postmitotic AIY neuron. TTX-3 and $\mathrm{CEH}-10$ then activate and maintain the expression of a battery of terminal differentiation genes throughout the life of the AIY neuron.

Figure 3 Role of the C. elegans Zic protein REF-2 in the response to Wnt signaling. Classic target genes are activated by the TCF: $\beta$-catenin complex and repressed by TCF in the absence of $\beta$-catenin. Opposite target genes are activated by a REF2:TCF complex and this activation is blocked by $\beta$-catenin.

\section{References}

Alper S, Kenyon C (2002) The zinc finger protein REF-2 functions with the Hox genes to inhibit cell fusion in the ventral epidermis of $C$. elegans. Development 129 (14):3335-3348

Altun-Gultekin Z, Andachi Y, Tsalik EL, Pilgrim D, Kohara Y, Hobert O (2001) A regulatory cascade of three homeobox genes, ceh-10, ttx-3 and ceh-23, controls cell fate specification of a defined interneuron class in C. elegans. Development 128 (11):1951-1969

Aruga J (2004) The role of Zic genes in neural development. Mol Cell Neurosci 26 (2):205-221. doi:10.1016/j.mcn.2004.01.004

Aruga J, Kamiya A, Takahashi H, Fujimi TJ, Shimizu Y, Ohkawa K, Yazawa S, Umesono Y, Noguchi H, Shimizu T, Saitou N, Mikoshiba K, Sakaki Y, Agata K, Toyoda A (2006) A wide-range phylogenetic analysis of Zic proteins: implications for correlations between protein structure conservation and body plan complexity. Genomics 87 (6):783-792. doi:10.1016/j.ygeno.2006.02.011 
Bertrand V (2016) beta-catenin-driven binary cell fate decisions in animal development. Wiley Interdiscip Rev Dev Biol 5 (3):377-388. doi:10.1002/wdev.228

Bertrand V, Bisso P, Poole RJ, Hobert O (2011) Notch-dependent induction of left/right asymmetry in C. elegans interneurons and motoneurons. Curr Biol 21 (14):1225-1231. doi:S0960-9822(11)00661-0 [pii] 10.1016/j.cub.2011.06.016

Bertrand V, Hobert O (2009) Linking asymmetric cell division to the terminal differentiation program of postmitotic neurons in C. elegans. Dev Cell 16 (4):563-575. doi:S1534-5807(09)00085-9 [pii] 10.1016/j.devcel.2009.02.011

Brenner S (1974) The genetics of Caenorhabditis elegans. Genetics 77 (1):71-94 Cadigan KM (2012) TCFs and Wnt/beta-catenin signaling: more than one way to throw the switch. Curr Top Dev Biol 98:1-34. doi:B978-0-12-386499-4.00001X [pii] 10.1016/B978-0-12-386499-4.00001-X

Cimbora DM, Sakonju S (1995) Drosophila midgut morphogenesis requires the function of the segmentation gene odd-paired. Dev Biol 169 (2):580-595. doi:10.1006/dbio.1995.1171

Clevers H, Nusse R (2012) Wnt/beta-catenin signaling and disease. Cell 149 (6):1192-1205. doi:10.1016/j.cell.2012.05.012

Fujimi TJ, Hatayama M, Aruga J (2012) Xenopus Zic3 controls notochord and organizer development through suppression of the Wnt/beta-catenin signaling pathway. Dev Biol 361 (2):220-231. doi:10.1016/j.ydbio.2011.10.026

Hobert O (2016) A map of terminal regulators of neuronal identity in Caenorhabditis elegans. Wiley Interdiscip Rev Dev Biol 5 (4):474-498. doi:10.1002/wdev.233

Hobert O, Mori I, Yamashita Y, Honda H, Ohshima Y, Liu Y, Ruvkun G (1997) Regulation of interneuron function in the $\mathrm{C}$. elegans thermoregulatory pathway by the ttx-3 LIM homeobox gene. Neuron 19 (2):345-357

Hoverter NP, Waterman ML (2008) A Wnt-fall for gene regulation: repression. Science signaling 1 (39):pe43. doi:10.1126/scisignal.139pe43

Kaletta T, Hengartner MO (2006) Finding function in novel targets: C. elegans as a model organism. Nat Rev Drug Discov 5 (5):387-398. doi:10.1038/nrd2031

Kaletta T, Schnabel H, Schnabel R (1997) Binary specification of the embryonic lineage in Caenorhabditis elegans. Nature 390 (6657):294-298. doi:10.1038/36869 
Layden MJ, Meyer NP, Pang K, Seaver EC, Martindale MQ (2010) Expression and phylogenetic analysis of the zic gene family in the evolution and development of metazoans. Evodevo 1 (1):12. doi:10.1186/2041-9139-1-12

Lin R, Hill RJ, Priess JR (1998) POP-1 and anterior-posterior fate decisions in C. elegans embryos. Cell 92 (2):229-239. doi:S0092-8674(00)80917-4 [pii] Lindgens D, Holstein TW, Technau U (2004) Hyzic, the Hydra homolog of the zic/odd-paired gene, is involved in the early specification of the sensory nematocytes. Development 131 (1):191-201. doi:10.1242/dev.00903

MacDonald BT, Tamai K, He X (2009) Wnt/beta-catenin signaling: components, mechanisms, and diseases. Dev Cell 17 (1):9-26. doi:S1534-5807(09)00257-3 [pii] 10.1016/j.devcel.2009.06.016

Mizumoto K, Sawa H (2007) Two betas or not two betas: regulation of asymmetric division by beta-catenin. Trends Cell Biol 17 (10):465-473. doi:S09628924(07)00204-8 [pii] 10.1016/j.tcb.2007.08.004

Murgan S, Bertrand V (2015) How targets select activation or repression in response to Wnt. Worm 4 (4):e1086869

Murgan S, Kari W, Rothbacher U, Iche-Torres M, Melenec P, Hobert O, Bertrand V (2015) Atypical Transcriptional Activation by TCF via a Zic Transcription Factor in C. elegans Neuronal Precursors. Dev Cell 33 (6):737-745. doi:10.1016/j.devcel.2015.04.018

Nelson FK, Riddle DL (1984) Functional study of the Caenorhabditis elegans secretory-excretory system using laser microsurgery. J Exp Zool 231 (1):4556. doi:10.1002/jez.1402310107

Oda-Ishii I, Kubo A, Kari W, Suzuki N, Rothbacher U, Satou Y (2016) A Maternal System Initiating the Zygotic Developmental Program through Combinatorial Repression in the Ascidian Embryo. PLoS genetics 12 (5):e1006045. doi:10.1371/journal.pgen.1006045

Phillips BT, Kimble J (2009) A new look at TCF and beta-catenin through the lens of a divergent C. elegans Wnt pathway. Dev Cell 17 (1):27-34. doi:S15345807(09)00258-5 [pii] 10.1016/j.devcel.2009.07.002

Pourebrahim R, Houtmeyers R, Ghogomu S, Janssens S, Thelie A, Tran HT, Langenberg T, Vleminckx K, Bellefroid E, Cassiman JJ, Tejpar S (2011) Transcription factor Zic2 inhibits Wnt/beta-catenin protein signaling. J Biol 
Chem 286 (43):37732-37740. doi:M111.242826 [pii]

10.1074/jbc.M111.242826

Sawa H, Korswagen HC (2013) Wnt signaling in C. elegans. WormBook:1-30. doi:10.1895/wormbook.1.7.2

Sulston JE, Horvitz HR (1977) Post-embryonic cell lineages of the nematode, Caenorhabditis elegans. Dev Biol 56 (1):110-156

Sulston JE, Schierenberg E, White JG, Thomson JN (1983) The embryonic cell lineage of the nematode Caenorhabditis elegans. Dev Biol 100 (1):64-119. doi:0012-1606(83)90201-4 [pii]

Sundaram MV, Buechner M (2016) The Caenorhabditis elegans Excretory System: A Model for Tubulogenesis, Cell Fate Specification, and Plasticity. Genetics 203 (1):35-63. doi:10.1534/genetics.116.189357

Takahashi H, Shimizu T, Aruga J (2008) Expression pattern of annelid Zic in embryonic development of the oligochaete Tubifex tubifex. Dev Genes Evol 218 (10):553-560. doi:10.1007/s00427-008-0252-x

Wenick AS, Hobert O (2004) Genomic cis-regulatory architecture and trans-acting regulators of a single interneuron-specific gene battery in C. elegans. Dev Cell 6 (6):757-770. doi:10.1016/j.devcel.2004.05.004 S1534580704001650 [pii] 
A

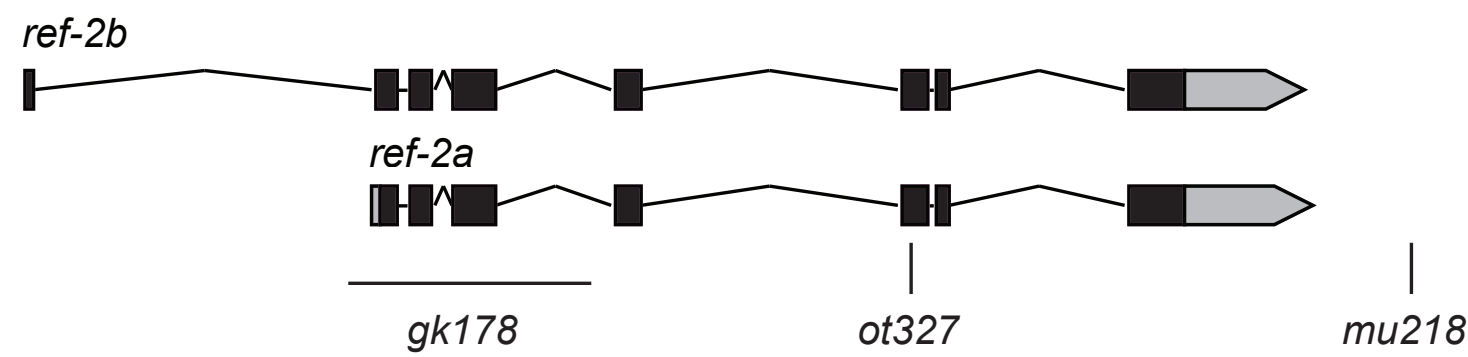

B

zinc finger 1

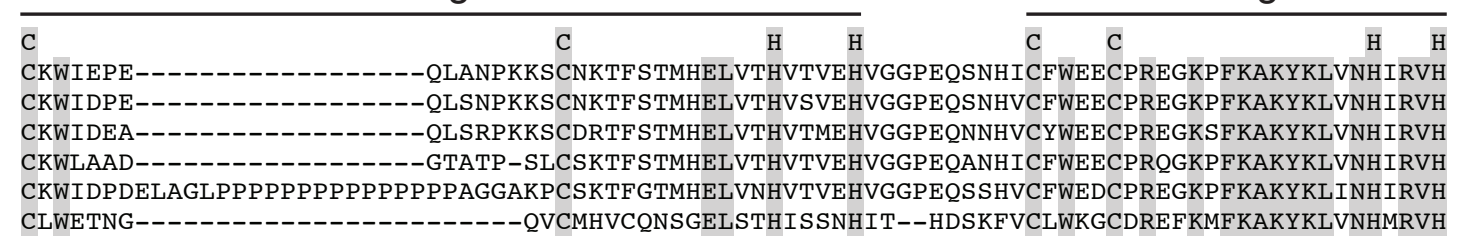

Hs-Zic 1

Hs-Zic 2

Hs-Zic 3

Hs-Zic 4

Hs $-\mathrm{Z}$ ic 5

Ce-REF-2

Hs-Zic 1

Hs-Zic 2

Hs-Zic 3

Hs-Zic 4

Hs-Zic 5

Ce-REF-2 zinc finger 3

\begin{tabular}{llll}
\hline $\mathrm{C}$ & $\mathrm{C}$ & $\mathrm{H}$ & $\mathrm{H}$
\end{tabular}

\begin{tabular}{llll}
\hline $\mathrm{C}$ & $\mathrm{H}$ & $\mathrm{H}$
\end{tabular}

TGEKPFPCPFPGCGKVFARSENLKI HKRTHTGEKPFKCEFEGCDRRFANSSDRKKHMHVHTSDKPYLCKM--CDKSYTHPSSLRKHMKVH TGEKPFPCPFPGCGKVFARSENLKIHKRTHTGEKPFQCEFEGCDRRFANSSDRKKHMHVHTSDKPYLCKM--CDKSYTHPSSLRKHMKVH TGEKPFPCPFPGCGKIFARSENLKIHKRTHTGEKPFKCEFEGCDRRFANSSDRKKHMHVHTSDKPYICKV--CDKSYTHPSSLRKHMKVH TGEKPFPCPFPGCGKVFARSENLKIHKRTHTGEKPFRCEFEGCERRFANSSDRKKHSHVHTSDKPYTCKVRGCDKCYTHPSSLRKHMKVH TGEKPFPCPFPGCGKVFARSENLKIHKRTHTGEKPFKCEFDGCDRKFANSSDRKKHSHVHTSDKPYYCKIRGCDKSYTHPSSLRKHMKIH TGERPFLCDV--CNKVFARSENLKIHKRIHSGEKPFQCTHNGCTKLFANSSDRKKHMHVHSSHKPYSCMYPDCGKTYTHPSSLRKHTKVH

ot327

Fig. 1 
AIY mother cell
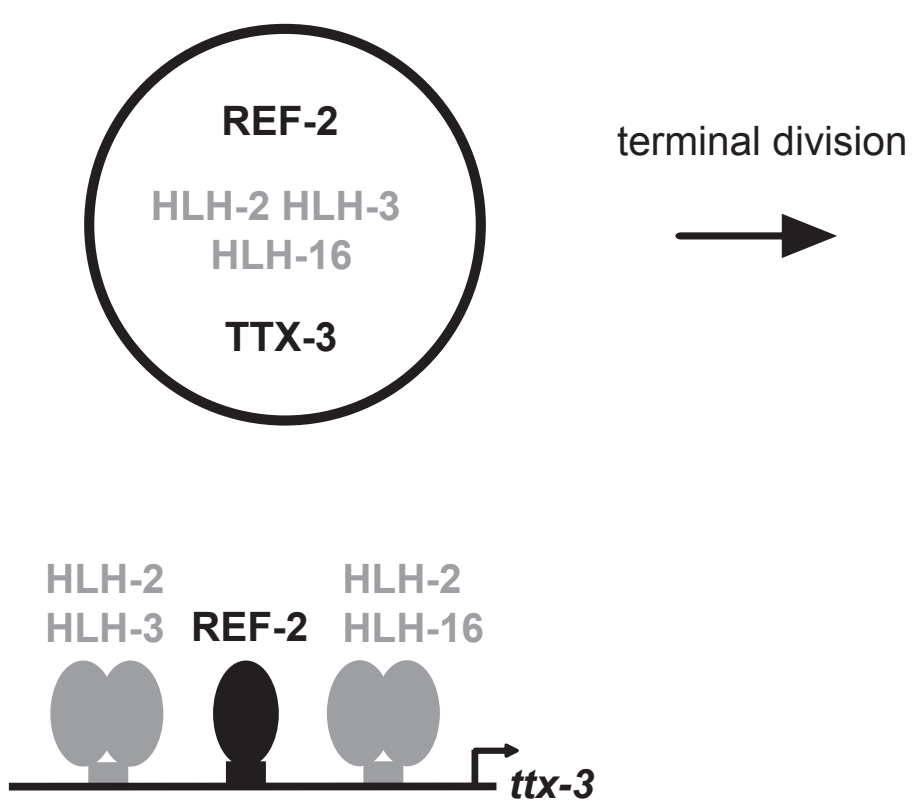

AIY postmitotic neuron

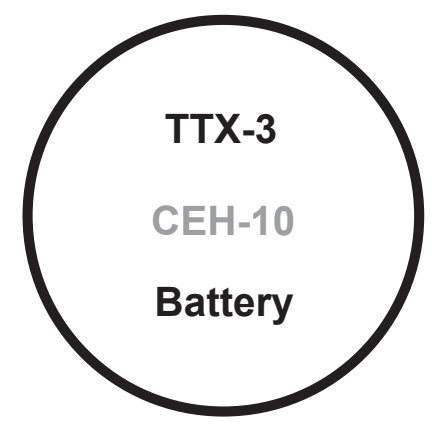

TTX-3 CEH-10

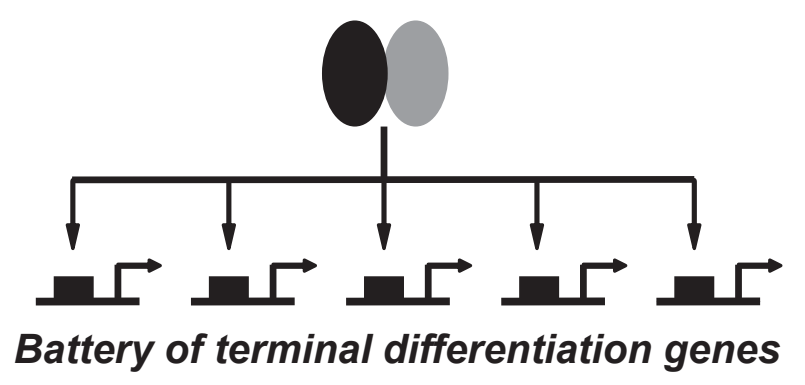

Battery of terminal differentiation genes
REF-2 : Zic

HLH-2 : Daugtherless

HLH-3 : Achaete-Scute
HLH-16 : Beta3

TTX-3 : LhX2/9

CEH-10 : CHX10

Fig. 2 


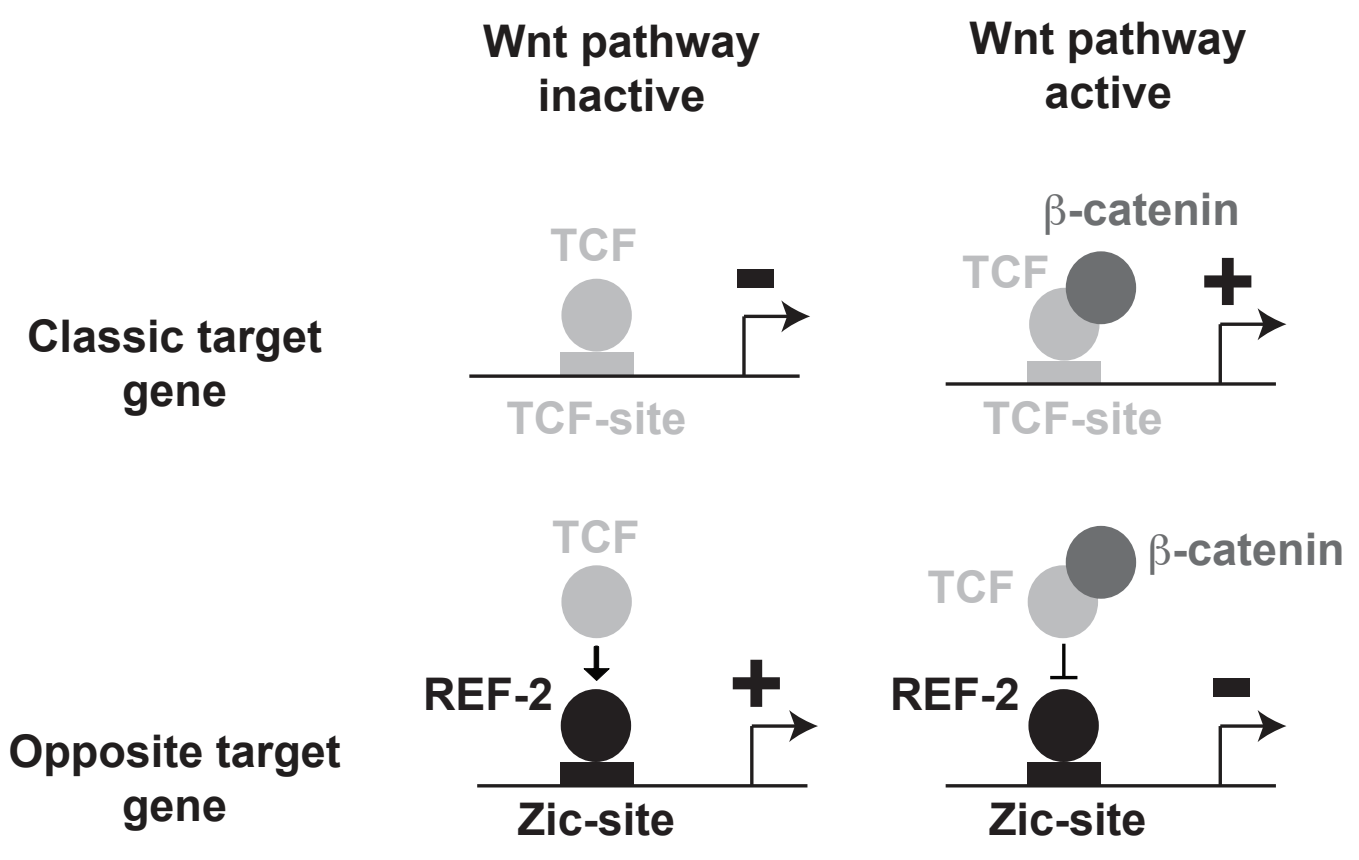

Fig. 3 